This is a self-archived version of an original article. This version may differ from the original in pagination and typographic details.

Author(s): Murtorinne-Lahtinen, Minna; Jokinen, Kimmo

Title: Stepmothers' constructions and negotiations of belonging

Year: 2020

Version: Accepted version (Final draft)

Copyright: (C) 2017 Informa UK Limited, trading as Taylor \& Francis Group

Rights: In Copyright

Rights url: http://rightsstatements.org/page//nC/1.0/?language=en

Please cite the original version:

Murtorinne-Lahtinen, M., \& Jokinen, K. (2020). Stepmothers' constructions and negotiations of belonging. Journal of Family Studies, 26(1), 51-66.

https://doi.org/10.1080/13229400.2017.1308877 


\section{Stepmothers' Constructions and Negotiations of Belonging}

\section{Introduction}

"Life has been a bit more surprising than I expected at one time. It started favourably enough; studying, finding a job, getting married and buying house. It is not very smart to get divorced before your $26^{\text {th }}$ birthday. - But that's how I ended up here. Like starting all over from the beginning. Everything changed: the town, the work place and the people around me, from being single to family life. I was a newcomer here, a stranger among interwoven histories."

Family transitions, like divorce and remarriage, set in motion of a series of changes that are potentially stressful for all members of the family (Hetherington \& Stanley-Hagan, 1995; Ganong \& Coleman, 2005). However, the family is usually seen natural, permanent, and self-evident structure. As Pierre Bourdieu has stated, the dominant, legitimate definition of the proper family is based on the idea that the family is a set of related individuals sharing the same household and linked by alliance or filiation. In recent years, however, such traditional family arrangements have undergone a visible decline. In fact, the very concept of the family is an arbitrary social construct. (Bourdieu, 1996.) Instead, in contemporary research, families are seen as a process, rich in forms and characterized by change, as described by Ann in the above quote. She, a stepmother of two school-aged children, exemplifies how multiple changes and discontinuities in her everyday relational and physical surroundings took place when she remarried.

Ann awoke to a feeling of not belonging to her new community and place; a feeling which is typical when belonging is disrupted (Bennett, 2012; May, 2015). The shared worlds of her new family were not available to the newcomer (Bennett, 2012). This generated in her feelings of being uprooted, which may have threatened her sense of self. The uncertainty 
caused by these changes may also have prompted her to undertake reflexive identity work. For example, she may have felt compelled to ask herself questions like "Where do I belong?" and "Where have I come from and where am I going?", since identity presumes a narrative that sustains an integrated sense of self (Giddens, 1991), and also feelings such as connectedness, embeddedness (Smart, 2007) and belonging.

Being a stepmother is the most challenging role in a stepfamily. According to the existing research, high levels of stress and maternal depression brought about by ambiguous role expectations is a common experience among stepmothers (Craig, Harvey-Knowles, \& Johnson, 2012; Doodson \& Davies, 2014; Hart, 2009; Shapiro \& Stewart, 2011). Previous studies have shown that lack of a sense of belonging is associated with vulnerability to depression and stress, which is linked to lower levels of psychological and social functioning (Choenarom, Williams, \& Hagerty, 2005; Hagerty, Williams, Coyne, \& Early, 1996). It has been suggested that promoting a sense of belonging in individual community members can support the health of the whole community (e.g. Hill, 2006). Thus, understanding the factors that enhance stepmothers' sense of belonging may promote the wellbeing of the whole family.

Applying a narrative approach to belonging, this study examines how Finnish stepmothers construct and negotiate their belonging in stepfamilies (drawing on data from a dissertation on stepmothers by Author 1, 2011). How do they do their belonging (Bennett, 2012) and what is the emotional content of (not) belonging? What factors foster or engender, and what, in turn, hinder stepmothers' sense of belonging, and how is this sense of belonging attained and by whom? No previous studies have explored how stepmothers construct and negotiate their belonging in stepfamilies. 


\section{Belonging}

Belonging, a basic human need, has been defined as a vital element for mental health and social wellbeing (e.g. Hagerty et al., 1996; Mahar, Cobigo, \& Stuart, 2013; Maslow, 1954/1970). Belonging is a relevant concept in this study since it is relational, and focuses on social interaction and intersubjectivity, and on their emotional content (May, 2015). The relational approach is also well justified in the light of previous stepfamily studies (e.g., Erera-Weatherly, 1996), which suggest that some of the difficulty stepmothers face can be attributed to their dependency on others (e.g., stepchildren, partner, biological mother). In addition, belonging is a multidimensional concept that allows us to explore stepmothers' experiences of intimate relationships from multiple perspectives. It is also a fluid concept, since our experience of belonging changes over time in response to others and in response to changes in ourselves. Moreover, belonging is fundamental to who and what we are. (May, 2015.)

The affective dimension of belonging, known as a sense of belonging, includes feelings that indicate perceived social support, such as feeling valued, needed, accepted and respected by other people. Overall the feeling of being accepted, safe and comfortable can be described as a 'feeling at home'. (Bell, 2016; Mahar et al., 2013; Salonen, Laakso, Sevón, 2016.) Another important affective dimension of belonging mentioned in the literature is the feeling of "fitting in" or experiencing congruence with other people and environments. This feeling is based on having similar or shared experiences, understandings and behaviors as those of the group (May, 2015; Strayhorn, 2012). Moreover, contextual factors, such as the age and place of residence of the stepchildren may be critical to the stepmother's sense of belonging (Coleman, Troilo, \& Jamison, 2008; King, 2007). Moreover, sense of belonging is grounded in the contexts which one desires or feels permitted to belong (e.g. Mahar et al., 2013). 
In contemporary family research, the meaning of intimate relationships has been a topic of lively debate. Alongside belonging, concepts such as connectedness, embeddedness and relatedness are also often used in this context. According to Carol Smart $(2007,17)$, family members are connected to each other, while relationships with the wider kin group and other close, family-like relationships also have an important meaning in most people's lives and are an integral part of their well-being (see also Finch \& Mason, 1993). Thus, relatedness, connectedness and belonging closely resemble each other. When we talk about belonging, we are aware of these similarities.

Much of the research on belonging has focused on the role of social networks and social support in relation to health outcomes (Hagerty et al., 1996). Irrespective of gender, the research findings support the view that social bonds and well-being are associated. However, in a sample of college students, Hagerty et al. (1996) found that overall sense of belonging seems to be more strongly related to both psychological and social functioning in women than in men. For women "fitting in" and feeling valued were important elements of the self. In the case of spousal support, Hagerty et al. (1996) found that lack of supportive, confiding and intimate interaction with one's spouse may have a stronger negative impact on women than men.

Similarly, perceptions that one's need for belonging is not met may lead to feelings of alienation and loneliness (Mellor, Stokes, Firth, Hayashi, \& Cummins, 2008). For example, the negative psychosocial experiences of stepmothers have been associated with feelings of insecurity and isolation (Jones, 2003). In the literature, these experiences have been linked to the prevailing misogynistic stereotyping of stepmothers, which may guide the perceptions of those in one's social network, including stepchildren. This could stigmatize stepmothers, negatively impacting their roles as wives and stepmothers and their self-esteem. (Ceglian \& Gardner, 2000; Christian, 2005; Craig \& Johnson, 2010; Watson, 1995.) The cultural 
dominance of the stepmother stereotype potentially renders stepmothers vulnerable to internalizing this portrait as a part of their personal identity, in turn causing them to struggle against its connotations of being evil and selfish (Church, 1999; Christian, 2005; Craig \& Johnson, 2010).

Morgan (1996; 2011) observes that qualities such as caring, responsibility and loving are often associated with the idea of 'family'. This kind of emotional work (Strazdins \& Broom, 2004) tends to be associated with the women - mainly mothers. It is a cultural norm in the Western world that only one woman can be properly responsible for this task - the biological mother. Thus, stepmothers commonly feel that they cannot inhabit the role of a 'real' mother, even though they feel responsible for providing care (Nielsen, 1999; Weaver \& Coleman, 2005). According to Shapiro and Stewart (2011), occupying a role that falls outside of the dominant societal norms puts stepmothers at increased risk for mental health problems.

Identity is about belonging, what you have in common with others and what differentiates you from them (Weeks, 1990). A sense of belonging is based on embodied memories, such as everyday habits, that become a part of who we are (Jackson, 1983; May 2015). Daily life is about habitual and routinized actions and many of these actions are culturally shared (Southerton, 2012).

In their historical overview, Fiese, Tomcho, Douglas, Josephs, Poltrock and Baker (2002) make a distinction between family routines and rituals. They define routines as repetitive and observable practices that convey continuity in behavior. A notable transition that may threaten family routines is divorce, and being able to maintain one's routines under potentially vulnerable conditions may contribute to parenting competence and child adaptation. Rituals, in turn, are symbolic and affective in nature, and give all members of the community a sense of belonging. However, rituals also construct boundaries, and so may exclude family members whose position in the family is ambiguous. 
Belonging is not, however, only based on shared culture (May, 2015). It also captures a dynamic view of doing belonging, such as the negotiation of membership and boundaries, which involves issues of power and hierarchies (Bennett, 2012; Jamieson, 2005). According to Morgan (1996), if, for example, the interest is in the relationship between an individual and society, or, as in our article, belonging and family relationships in stepfamilies, the analysis should not end at the boundary of any particular unit selected as a theoretical whole, whether this unit is an organization or a household.

In the literature, stepfamilies have been associated with ambiguous family boundaries. This ambiguity refers to a lack of clarity as to who is in and who is out of the family. Incompatible perceptions of family membership have been reported to negatively affect stepfamily functioning. (Craig \& Johnson, 2011.) Stewart (2005) suggests that boundary ambiguity is associated with the structure of the stepfamily. Specifically, a much higher proportion of couples with non-resident stepchildren have ambiguous family boundaries than couples who only have resident stepchildren.

\section{Method}

\section{Participants and Data Collection}

The empirical data consisted of 58 stories written by stepmothers. The inclusion criteria were that the women identified themselves as stepmothers and were living with a man who had children from a previous marriage. The participants replied to announcements published in a newspaper, a popular magazine, and on the websites of the Finnish Stepfamily Association. The newspaper and the magazine are wide circulation publications reaching middle-aged people from diverse family backgrounds. The instruction to potential participants was the following: "We are conducting research on stepmothers. If you have experiences of step mothering, please write to us. Tell us about things that are important to you in this role." In addition, we asked them to describe "the joys, sorrows, difficult 
situations and moments of happiness as well as the obligations and rights of life as a stepmother". The accounts were rather short, mean length two pages, but most were written in the form of a story with a beginning, middle and end.

The stepmothers, ranging in age between 23 and 73 ( $M=41$ years), lived in both rural and urban areas. They had lived in their stepfamilies for 1 to 38 years, and the ages of the stepchildren ranged from 1 to 43 years. Of the stepmothers, 45 per cent had biological children and 40 per cent had children from the current relationship. A total of 34 per cent of the stepmothers resided with their stepchildren and 28 per cent non-residential, while 38 per cent could not be categorized in either group because their residential status changed over time. Most of the respondents worked full time. The majority of the participants did not see the need to include information about their educational or occupational background in their story.

Ethical approval was sought from the University of Jyväskylä Ethical Committee, but it did not request a statement on this study. We nevertheless paid special attention to ethical issues and discussed them with the respondents via email. The participants were informed of the possibility to withdraw their personal story at any stage of the research and of the option to deny the usage of direct quotations from their stories. All names of stepmothers and their family members in this paper are pseudonyms.

\section{Narrative Approach and Data Analysis}

The theoretical framework outlined above was complemented by a narrative approach. Narratives are seen as central means by which identities, and belonging as an important aspect of identity, are produced (Hänninen, 2004; Polkinghorne, 1988). Writing a story allowed the informants to explain what they felt, though and believed about their close relationships. In addition, the focus on human agency steered attention to the ways stepmothers depicted their agency and power relations (Riessman, 1993), while the narrative 
analysis also enabled identity construction to be explored from a procedural point of view (Somers, 1994).

We approached the analysis in phases. We began by carefully reading the stories to extract the essential content of each story and to comprehend the stepmothers' perceptions of their family relations, interactions, and thus belonging. In the second phase, we analyzed onethird of the stories systematically, using set questions, such as: "What is the stepmother's role in interaction with the other members of the family?" We paid attention to the narrative structure of the stories, to the thematic connections between them and to the congruencies and incongruences between stories. Comparison of the stories showed that while the complicating actions were similar, the resolutions varied. In the final, deductive phase, the findings were compared to previous findings, and all the stories were classified into one of three types of belonging.

\section{Results}

\section{Three Types of Belonging}

The predominant feature in all the stories was that the stepmother felt threatened by the biological mother. The stories had, however, various outcomes depending on the family context and stepmothers' and their family members' ways of doing belonging. Based on these outcomes, three types of belonging were found: (a) weak sense of belonging ( $N=24)$, (b) dyadic stepmother-stepchild belonging $(\mathrm{N}=17)$, and (c) spousal relationship as a focal dyad of belonging $(\mathrm{N}=17)$. A story may have exhibited features of more than one type. Belonging was characterized as a process, and a particular stepmother may have shifted from one type to another, if for example a stepmother had been a stepmother for longer period of time. Time sometimes altered stepmothers' sense of belonging but not always. Some relationships appeared to be non-negotiable and tensions remained. 


\section{Weak Sense of Belonging}

The 24 stepmothers comprising this type were identified as socially, spatially and culturally marginal. They appeared not to have developed a sense of belonging in any dyadic family relationships or in the family as a whole (see also King, Boyd, \& Thorsen, 2015). Moreover, they were prone to internalize the stigma associated with step-motherhood. Partially these stepmothers felt excluded from full family membership, and partially they withdrew to avoid tension associated with interaction with their stepchild(ren). They attributed their inability to attain a sense of belonging in relation with their stepchild to their dependency on the biological mother and father. On the other hand, their stepmotherhood was neither a chosen nor desired state, as one of them pointed out. This identity type commonly occurred in families with non-residential teenagers or older children.

The biological mother appeared to be actively present in in the stepfamily in either concrete or psychological ways. This was linked to boundary ambiguity. The stepmothers criticized the biological mother for "interfering" and "intruding" in the stepfamily"s life "as if she was still living with her ex-partner". On the other hand, from the biological mother's point of view it could be just "normal" maternal care. Yet, it was seen as a challenging situation for those stepmothers who were seeking to create family belonging. One stepmother, Rita, attributed the rejecting behavior of her stepchild to the behavior of the biological mother who had advised her daughter not to consider Rita "as her mother and John (Rita's son) ever as her brother". Habit discontinuity (Southerton, 2012) and being without a clear role engendered feelings of "uselessness" and "irritation", and seemed to shake these stepmothers' ontological security (Giddens, 1991).

A common experience was that the biological mother restricted the stepmother's engagement in parenting practices. She was reported to undermine the stepmother's parental authority by bad mouthing her and contravening rules established at the father's place of 
residence. Stepmothers were labeled, for example, as "housekeepers" who had "no right to get involved in the upbringing of the biological mother's children.'It was through this disruption of practices that the boundaries of outsider, of not belonging, were formed (Allan, Crow, \& Hawker, 2011).

Some stepmothers reported that they had no input in decision making concerning the stepchildren, which in turn impacted on their right to self-determination. Others saw a gap between parental duties and rights. They felt that they put a lot of effort into their relations with their stepchildren without "acknowledgement from anyone". Lacking recognition, they felt exploited and non-appreciated. In addition, stepmothers were blamed for the breaking up of the family.

Clearly, the tensions between the two mothers were linked to issues of belonging. To the stepmother, the notion of the biological mother-child dyad was exclusive (see also Jamieson, 2005). When the biological mother showed no desire to share the practices of intimacy and parenting with an outsider, the stepmother had to adjust to a non-normative pseudo-parental role for which they had no role model (see e.g. Allan et al., 2011; Doodson \& Morley, 2006). Their frustration may be an outcome of the feeling of not "fitting in" to the prescriptive norms of motherhood.

The relationships of some of the non-residential stepmothers with their stepchildren were seen as problematic owing to disputes between the biological parents. The biological mothers were blamed for sabotaging appointments between fathers and their children. "Their mother always came up with something that needed to be done during the time when the boys were supposed to visit us boys' visit us. The boys should have stayed with us from Friday to Sunday, but they usually only stayed for a few hours on Saturday." This was interpreted as a form of estrangement. 
Some stepmothers depicted their spouses as career engaged and absent fathers. It may be, as Smart and Neale (1999) point out, that mothers tend to see themselves as both responsible for and more experienced in childcare makes the transition to post-divorce parenthood hard. Thus, for some parents, the traditional gender contract continues a pattern of parenting post-divorce.

Lengthy legal proceedings over child custody, visitation rights and child maintenance were common experiences among non-residential stepmothers. A high level of conflict between the spouses and limited contact with the child was associated with a low sense of belonging (see also Hill, 2006). Many stepmothers characterised their husbands as passive and permissive with their children, which in turn seemed to render the stepmother vulnerable in her relation with the child(ren). It may be that the non-residential father feared that the children would choose not to visit return him if he imposed behavioural boundaries (Henry \& McCue, 2009).

"Nowadays we're not talking to each other (the boys and I). Except when the teenage one calls me a whore. I can't accept this sort of behaviour. Still, what hurts me most is the fact that my husband doesn't dare to intervene in the matter. "

Space was an integral part of who the stepmothers were. As could be expected, these stepmothers did not feel at home when their stepchildren came for a visit and "hardly greeted" them. Such continuing tensions contributed to their spatial withdrawal. They escaped to their own room, if they had one, or went out. They indicated that this in turn intensified their sense of not-belonging to the family. In their new home they felt alienated and isolated, like "astronauts on a strange planet". The anxiety of not belonging, of not being accepted as full members of the family, could provoke bodily reactions, physical symptoms of "feeling sick". 
In addition, these stepmothers felt that the stepchildren's needs were prioritized over theirs. The stepchildren, for example, slept in the double bed and the stepmother in the children's bed. As a result, they were inclined to feel excluded, jealous, bitter and depressed. One stepmother reported having had suicidal thoughts. Moreover, because the stepmothers experienced negative feelings in relation to their stepchildren, they tended to feel that they were wicked (Church, 1999). It may be that because the father's time with the children was limited to their visiting hours, his attention was focused exclusively on his children. He may have felt that his sense of belonging was threatened by post-divorce custodial arrangements in which the mother was considered the primary caretaker.

Establishing family unity was regarded as challenging. The stepmothers felt excluded from family memories, histories, traditions and ceremonial or daily rituals which further contributed to their sense of not belonging to the family (see also Banker \& Gaertner, 1998). As new additions to the family they felt positioned as outsiders in the "we-ness" of the family core. Thompson (1996) argues that contact between different traditions can also promote intensified forms of boundary-defining activity to protect the integrity of one's own group's traditions and re-affirm forms of collective identity by excluding others.

"Somehow I feel that I'm the problem nowadays. I claim more family membership than I've got. The girls usually come and express their opinions in we-mode. When

I'm irritated I call them WEGIRL. We-girl means an impersonal past, which allows her not to take responsibility for her words or actions."

\section{Dyadic Stepmother-stepchild Belonging}

The 17 stepmothers comprising this type saw themselves as mother figures and 'executive managers' responsible for co-ordinating family life. Thus, they conformed to the cultural expectations characteristic of the metanarrative of intensive mothering, which accords the mother a central role in raising the children (Hart, 2009; Parsons, 1956; Perälä- 
Littunen, 2007). As in the nuclear family ideology, several of the fathers were careerengaged, leaving responsibility for the family with the stepmother.

Sense of belonging seemed easier to attain in this stepmother type as young children were more frequently resident in the household than in those of the other two types and the biological mother appeared to be less actively involved in her children lives than in the first type. Some stepmothers discussed social ties and biological analogies (also Ribbens, McCarthy, Edwards, Val Gillies, 2003). Compared to a blood tie, the social relationship was considered more negotiable as it was seen to be dependent on the biological parents' willingness to share the emotional dimension of the relationship. The wicked stepmother stereotype was not an issue in these stories.

These stepmothers actively negotiated their belonging with their stepchildren. They presented themselves as committed and proper parents who invested time in childcare activities, thus deserving their stepchildren's confidence. At the beginning of their stories, the stepmothers focused on the evolution of their sense of belonging in the stepmother-stepchild dyad. The stepmothers' sense of belonging was expressed through related feelings of happiness, satisfaction and gratitude.

The father's role seemed peripheral; at least until stepchild-stepmother intimacy was achieved. Active support by her partner of the stepmother's sense of belonging was not perceived as automatic. "I had to fight for this position, as the father eventually couldn't/ didn't want to help me. This was not the easiest path, but at least the outcome is good". Moreover, unlike in the first and third type, the spousal relationship was not reflected on.

The stepmothers were said to gain a sense of self-determination and parental power as moulders of the future generations through active doing. Developing a sense of belonging-inplace and identifying with that place was an integral part of personal identity. Doing belonging was also presented in terms of decor (see Bennett, 2012; Morgan, 1996): "My own 
pictures on the walls, and I am a bit more the lady of the house. I don't try to live on my partner's and stepchildren's terms anymore."

The next details the dynamic process of creating a sense of belonging between a stepmother, Lisa, and her stepson, Joshua, through negotiation of the house rules and routines. Lisa's 5-year-old stepson refused to drink liquids with his meals, as a consequence of which he suffered abdominal pain. Lisa allowed Joshua to choose between a half and a full glass of milk, thus teaching the child to take responsibility for his behaviour at a level appropriate to his developmental stage. The child challenged Lisa's right to impose new house rules by defining his family biologically. Lisa responded to his anger by providing physical closeness: she calmed him down by "cuddling the child in her arms".

Because Lisa felt that the child had assumed that she was monitoring him out of personal antagonism, she created a sense of belonging through verbal communication. She sought to convince the child, also by writing the new house rules on a board, that setting limits was a form of caring. Joshua's inquiry about having the board in his room appeared as sign of his gradual acceptance of new house rules and routines. The authoritative parenting style (loving, demanding and understanding) described above slowly generated in Joshua a sense of belonging manifested in feelings of security, trust and affection.

After such episodes of turbulence, all the family members were able to situate themselves in the everyday life of the family, "everyone had their own role in the everyday routines". Joshua participated in such family practices, as shopping and baking, which further confirmed Lisa's and Joshua's mutual sense of belonging.

Another stepmother, Eva, had married a widower who was the father of one and a half year old John. At the beginning of their courtship, Eva's partner's mourning for his deceased spouse was said to be incomplete. When Eva took over the biological mother's functions, the husband was narrated as an act of disloyalty to his beloved first wife's memory. From the 
perspective of belonging, Eva's husband continued to feel a sense of connectedness to his deceased wife, who was thus still psychologically present. Perhaps, owing to the ideal of monogamy in our culture, Eva's husbands' feelings were ambivalent.

When John developed the habit of calling Eva his mom, the family members' responses to this were linked to issues of belonging, loyalty and ideas of kinship. John's grandmother "corrected him whenever he called Eva mom and reminded John about his mother". At the age of four John was articulated to show symptoms of anxiety. He had lost his mother but was not allowed to bond emotionally with his stepmother. Thus, in his own words he "belonged to the grave" and "wished to die". Alarmed by his reaction, Eva said that she and her husband contacted professionals who supported John's initiative in calling Eva his mother and suggested that his biological mother could be called his previous mother. This was explained to John's grandmother as well. At the end of the story stepfamily belonging had been achieved: "we are now a really close-knit family", as Eva described it.

At the end of the story Eva and many other stepmothers like her discussed their exhaustion. The gender imbalance in the affective dimension of belonging had contributed to their emotional distress (see also Strazdins et al., 2004). Some expressed ambivalent feelings towards their stepchildren while others saw a tension between belonging, and being a unique, "separate individual" (see also May, 2015). Possible interpretation is that, in order to cope with the tension, they attempted to re-negotiate their sense of belonging by balancing their need for individuality with their need for belonging. In practise, this meant sharing the parenting of their stepchildren with their spouse and if possible, with the biological mother. When the stepmother-child dyad was supplemented by a third person, the father, stepmothers indicated that the emotional work was more evenly distributed. 


\section{Spousal Relationship as a Focal Dyad of Belonging}

The 17 stepmothers comprising this third type emphasized the active role played by their spouse in their attaining of a sense of belonging in the family. In these families, men and women shared child-rearing and housework more equally than in the other types. Moreover, the couples referred to themselves gender neutrally as adults and parents, and laid emphasis on the fair and equitable treatment of children. This type could reflect the Finnish context, in which men's participation in child care and domestic labour has been increasing in recent years, and new representations of parenthood are on the rise (Jokinen \& Kuronen, 2011). The stepchildren in these families were more often of elementary school age than those in the families with the other two stepmother types.

The spousal relationship was constructed as a focal dyad of belonging, and as such the basis of the family (also Ribbens et al., 2003). The spouses formed a team which "worked toward the same goal". In a few cases, the team was said to include other adults considered to be in a position of responsibility for the children, such as the biological mother, aunts, uncles and schoolteachers.

In the majority of the stories, no tension was discussed to exist between the intimate spousal relationship and family life with children (also Ribbens et al., 2003). Working as a team appeared to diminish the possibility that alliances could develop (see e.g. Golish, 2003). In fact, the spousal relationship was seen as encompassing the children, whose needs for belonging were taken into account. Love was perceived as a non-finite resource that was shared. "Children are part of this package" and "there is enough love for everyone in this family."

In the stories, a spousal relationship based on emotions and equally shared parenthood were closely intertwined. By supporting their partners' authority as the other parent or adult of the family, the biological fathers were told to enhance their wives' sense of belonging as 
equal, respected and accepted members of the family. Clinicians often refer to a strong couple bond as one of the primary preconditions for a functional stepfamily (Ganong \& Coleman 2004). Dyadic time and self-disclosure were significant elements in doing belonging (see also Jamieson, 2005). Shared meanings, rules and routines were considered as the outcome of a process of negotiation. The stepmothers praised their partners for allowing them to freely show their emotions related to their stepchildren, even the ambivalent ones. All this nourished a sense of belonging between the partners.

"The biggest difference [compared to my previous marriage] is in the spousal relationship, namely in its functionality: in this family we have two equal parents, not primary and secondary, but on the same level, supporting, appreciating, encouraging and loving each other in good and bad times. This family would not exist without mutual love and trust."

"I think we have managed only because we have been able to discuss everything. We have spent hours having strong disagreements, in which we have analysed our emotions for each other."

Although these stepmothers also appeared to feel threatened by the biological mother, they indicated that their strong sense of belonging, being a unit, "we", rather than separate individuals, made them feel stronger. Having a strong couple bond served as a buffer at times when other family relationships, such as with teenage stepchildren and the biological mother, were stressful (see Ganong \& Coleman 2004). One stepmother described her situation as follows: "Our emotional bond was very strong right from the beginning. Without it I would hardly have been able to cope with everything that faced during these years." Another said that "having a solid couple bond helps, among other things, when we get feedback from the mother". 
The stepmothers shared the view that family rituals, such as "festivities during holiday seasons" and holiday travelling, contributed to all the family members' sense of belonging (Oswald, 2002). Maintaining some of the pre-stepfamily rituals and creating new ones was seen as a way of constructing a family identity. "What really unifies us is that we create our own, new traditions." Furthermore, shared routines, such as preparing meals and spending leisure time together during weekends and having fun, created a sense of connectedness.

In these stepmothers' stories, their relationships with their stepchildren varied. Although the stepmothers stressed the equal sharing of parental duties and rights, the building of the emotional relationship was depicted as a dyadic process. Most of the stepmothers characterized their relationships with their stepchildren as close and affectionate; only a few saw them as problematic. They seemed skilled in doing belonging with their (step)children as well. The stepmothers who were non-residential were seen as adult friends or mentors whom the children could confide in.

The children responded positively to the stepmothers' initiatives in creating a sense of belonging by simply being with them or hugging them and verbalizing their feelings: "You are the best stepmother in the world". However, in spite of their success in creating a confidential relationship, the stepmothers still felt a need to combat the myth of the wicked stepmother, for example, by avoiding the label stepmother, indicating that the stigma related to stepmothers is still alive in present-day Finland.

It is noteworthy that, in their personal stories, the stepmothers' practices did not end at the boundary of any particular unit, such as the household (Morgan, 1996). Anna, for example, had always been career-engaged and hardworking. She described her ambivalent feelings in relation to her stepchildren. She felt a sense of belonging with her stepson but not with her stepdaughter. She felt like "an outsider" in her stepdaughter's life. Her professional 
identity and sense of being valued at work compensated for her feelings of defeat at home. Friends and studies were also mentioned as important sources of belonging and identity that had an empowering effect on the stepmothers.

\section{Discussion}

The overall aim of this study was to examine how, in their written stories, stepmothers constructed and negotiated their belonging in stepfamilies. We asked how they did their belonging and what the emotional content of belonging was. Moreover, the factors that fostered and hindered stepmothers' sense of belonging were explored. The predominant feature of the stories was that the stepmothers felt threatened by the biological mother. The stories had, however, various outcomes depending on the family context and the stepmothers' and their family members' ways of doing belonging. Three types of belonging were identified: (a) weak sense of belonging, (b) dyadic stepmother-stepchild belonging, and (c) the spousal relationship as a focal dyad of belonging. Belonging was characterized as a process, and a particular stepmother may have shifted from one type to another. Moreover, a story may exhibit features of more than one type.

Belonging was the result of dynamic practices (May, 2015). Yet, the stepmothers indicated that they were dependent on the willingness of their spouses and the biological mother to share parenting and child-care related practices with them. In the first type, the biological mothers appeared to protect and defend their sense of belonging to their child(ren) by excluding the stepmother from aspects of parenting. The stepmothers implied that there was a connection between the biological mother's behaviour, the stepchild's resistance and the stepmother's failing to attain a sense of belonging. The tensions apparent between the two 'mothers' may be linked to exclusive notions of motherhood (also Shapiro \& Stewart, 2011). 
In the second type, the stepmothers focused on the stepmother-stepchild dyad until the intimacy and closeness was built. In their stories, they depicted the development of belonging as an active process of negotiation of practices and house rules. In the third type, the spousal relationship was considered a focal point of belonging. Intimates were described as if surrounded by a protective barrier that kept out the distracting behaviour of the biological mother (see also Jamieson, 2005). The spousal relationship, however, encompassed the children and the needs of the children to belong were considered. Feelings of love and happiness were not envisaged as decreasing when shared. Although the stepmothers' focused on shared family practices, the building of the emotional relationship appeared to be a dyadic process.

While conceptualizations of family belonging and dyadic belonging were separate constructs (King et al., 2015), they were also intertwined. Attaining a sense of dyadic belonging contributed to the sense of belonging to the family. Thus, these findings may unveil, some of the dynamics of belonging in family relationships in general and contribute, for their part, to family studies. Overall, the sense of belonging to a minimum of one person, or to a place, or being engaged in some practise (family, work, and hobby) appeared to be anchors in the world and in the everyday and thus important aspects of mental health (Hagerty et al., 1996; Hill, 2006). Vandemark (2007) has similarly established that attachment to place is central to self-identity, the sense of belonging, and the ability to be and to do in the world.

Stepmothers are a marginal group because of the stigma associated with them. Their marginality is social in nature, and as such not obvious but hidden (see also Goffman, 1963; Dainton, 1993). Moreover, all the present stepmothers experienced some disruptions in their sense of belonging and felt more or less dependent on the biological mother and father. For these reasons, they may have to negotiate their sense of belonging to feel that they are on 
equality with the other members of their family and society more actively than, for example, mothers in two-biological-parent families do.

Yet some of them did not achieve a sense of belonging. It is common for the stepmothers and the stepchildren to have ambivalent feelings about one another, at least at times in their relationship. In some cases these tensions remain. (Allan et al., 2011.) Thus, the practical implication of this study is that the spousal relationship is central in the stepfamily. It is important to better understand qualities of the spousal relationship that enhance the sense of belonging of the stepmother. Given the unique issues that stepmothers face in stepfamilies, the concept of belonging is a useful approach in studying stepmothers' experiences of intimate relationships in stepfamilies. It is important to get some insight of other factors related to family members' wellbeing besides the ones that contribute to stepfamily functioning. Other avenues, such as friendship groups, work communities and stepmothers' biological children and family of origin may also compensate stepmothers' weak sense of belonging with their stepchild (and with the spouse). This, however, merits further studies.

One key factor, aside from the age of the stepchildren, was the children's various living arrangements. Boundary ambiguity was more typically perceived in families with nonresident adolescent or older children (see also Stewart, 2005) and appeared to complicate the building of belonging in the stepmother-stepchild (and father) relationship. The "primary caretaker" norm may be likely to maintain conflict-prone post-divorce parental relations and the marginalization of stepmothers (see Lambert, 1997). Whether joint physical custody would diminish the threat stepmothers experience in relation to the biological mother, merits study in greater detail. According to Nielsen (2014), joint physical custody was likely to decrease the negative impact of high, ongoing conflict between ex-spouses.

Another point of interest was that belonging was not experienced wholly as positive, if the stepmothers saw it as threatening the balance between individuality and belonging (see 
Bornholt, 2000). An important element that threatened this balance was women's greater managerial responsibility for the smooth operation of the family, the emotional work (Duncombe \& Marsden, 1993). The active involvement of both spouses in emotional work contributed to solving this imbalance.

The stepmothers' sense of belonging or not belonging was manifested, for example, in feelings of happiness and acceptance, or in depression and anxiety. Clearly, how far stepmothers feel a sense of belonging in stepfamilies has a bearing on the wellbeing of the children. Furthermore, we know very little about how children (King et al., 2015) or biological mothers and fathers perceive family belonging. Hence further research is needed. In conclusion, this study contributes to understanding of the different ways in which stepmothers construct and negotiate their belonging in their families and the factors that enhance or hinder their belonging. Overall, the results suggest that the spouse was in a crucial position in enhancing a stepmother's sense of belonging

\section{References}

Allan, G., Crow, G., \& Hawker, S. (2011). Stepfamilies. Hampshire: Palgrave Macmillan. Bennett, J. (2012). Doing belonging: A sociological study of belonging in place as the outcome of social practices (Unpublished doctoral dissertation). The University of Manchester, Faculty of Humanities, UK.

https://www.escholar.manchester.ac.uk/api/datastream?publicationPid=uk-ac-man$\underline{\text { scw: } 184723 \& \text { datastreav }}$

Banker, B. S., Gaetrner, S. L. (1998). Achieving step-family harmony: An intergrouprelations approach. Journal of Family Psychology, 12, 310-325.

Bell, V. (1999). Performativity and belonging. An introduction. Theory, Culture \& Society, $16,1-10$.

Bornholt, L. J. (2000). Social and personal aspects of self-knowledge: a balance of 
individuality, and belonging. Learning and Instruction, 10, 415-429.

Bourdieu, P. (1996). On the family as a realized category. Theory, Culture \& Society, 13, 1926.

Ceglian. C. P., \& Gardner, S. (2000). Attachment style and "the wicked stepmother spiral". Journal of Divorce \& Remarriage, 34, 111-129.

Christian, A. (2005). Contesting the myth of the wicked stepmother: Narrative analysis of an online stepfamily support group. Western Journal of Communication, 69, 27-47.

Church, E. (1999). The poisoned apple: stepmothersexperience of envy and jealousy, Journal of Feminist Family Therapy, 11, 1-18.

Choenarom, C., Williams, R. A., \& Hagerty, B. M. (2005). The role of sense of belonging and social support on stress and depression in individuals with depression. Archives of Psychiatric Nursing, 19, 18-29.

Coleman, M., Troilo, J., \& Jamison, T. (2008). The diversity of stepmothers: The influences of stigma, gender and context on stepmother identities. In J. Pryor (Ed.), The international handbook of stepfamilies: Policy and practice in legal, research, and clinical environments (pp. 369-393). Hoboken, NJ: Wiley.

Craig, E. A., Harvey-Knowles, J. A., \& Johnson, A. J. J. (2012). Childless stepmothers: Communicating with other stepmothers about spouses and stepchildren. Qualitative Research Reports in Communication, 13, 71-79. doi:10.1080/17459435.2012.722164

Craig, E. A., \& Johnson, A. J. (2010). Role strain and online support for childless stepmothers. Journal of Social and Personal Relationships, 28, 868-887.

Dainton, M. (1993). The myths and misconceptions of the stepmother identity. Family Relations, 42, 93-98.

Doodson, L., \& Morley, D. (2006). Understanding the roles of non-residential stepmothers. Journal of Divorce \& Remarriage, 4, 109-130. 
Doodson, L. J., \& Davies, P. C. (2014). Different challenges, different well-being: A comparison of psychological well-being across stepmothers and biological mothers and across four categories of stepmothers. Journal of Divorce \& Remarriage, 55, 4963. doi: 10.1080/10502556.2013.862094

Duncombe, J., \& Marsden, D. (1993). Love and intimacy: the gender division of emotion and 'emotion work'. Sociology, 27, 221-241.

Erera-Weatherly, P. (1996). On becoming a stepparent: Factors associated with the adoption of alternative step parenting styles. Journal of Divorce \& Remarriage, 25, 155-174.

Fiese, B. H., Tomcho, T. J., Douglas, M., Josephs, K., Poltrock, S., \& Baker, T. (2002). A review of 50 years on naturally occurring family routines and rituals: Cause for celebration. Journal of Family Psychology, 4, 381-390.

Finch, J., \& Mason, J. (1993). Negotiating family responsibilities. London: Routledge. Ganong, L. H., \& Coleman, M. (2004). Stepfamily relationships. Development, dynamics and interventions. New York, NY: Plenum Publishers.

Ganong, L., \& M. Coleman (2005). Measuring intergenerational obligations. Journal of Marriage and Family, 67, 1003-1011.

Giddens, A. (1991). Modernity and self-identity. Self and society in the late modern age. Cambridge: Polity Press.

Goffman, E. (1963). Stigma: Notes on the management of spoiled identity. New York, NY: Touchstone Book Simon \& Schuster.

Golish, T. D. (2003). Stepfamily communication strengths. Understanding the ties that bind. Human Communication Research, 29, 41-80.

Hagerty, B. M. K., Williams, R. A., Coyne, J. C., \& Early, M. R. (1996). Sense of belonging and indicators of social and psychological functioning. Archives of Psychiatric Nursing, X, 235-244. 
Hart, P. (2009). On becoming a good enough stepmother. Clinical Social Work Journal, 37. doi: 10.1007/s10615-009-0202-8

Henry, P. J., \& McCue, J. P. (2009). The experience of non-residential stepmothers. Journal of Divorce and Remarriage, 50, 185-205.

Hetherington, E. M., \& Stanley-Hagan, M. (2002). Parenting in divorced and remarried families. In M. H. Bornstein (Ed.), Handbook of parenting. Being and becoming a parent (Vol. 3) (pp. 287-315). Mahwah, NJ: Erlbaum.

Hill, D. L. (2006). Sense of belonging as connectedness, American Indian worldview and mental health. Archives of Psychiatric Nursing, 20, 210-216.

Hänninen, V. (2004). A model of narrative circulation. Narrative Inquiry 14(1), 69-85.

Jackson, M. (2002). Belonging: towards a theory of identification with space. In J. Hiller \& E. Rooksby (Eds.), Habitus: A sense of place (pp. 281-295). Aldershot: Ashgate.

Jamieson, L. (2005). L. Boundaries of intimacy. In L. McKee \& S. Cunningham-Burley (Eds.) Families in society: Boundaries and relationships (pp. 189-206). Bristol: Policy Press.

Jones, A. C. (2004). Transforming the story. Narrative applications to a stepmother support group. Families in Society, 85, 129-138.

King, V. (2007). When children have two mothers: Relationships with nonresident mothers, stepmothers, and fathers. Journal of Marriage and Family, 69, 1178-1193.

King, V., Boyd, M., \& Thorsen, M. L. (2015). Adolescents' perceptions of family belonging in stepfamilies. Journal of Marriage and Family. doi: 10.111/jomf. 12181

Lambert, J. D. (1997). Post-divorce father involvement: Innovations in child Custody reform. Michigan Family Review, 3(1) 65-83. Retrieved from http://hdl.handle.net/2027/spo.4919087.0003.106 
Mahar, A. L., Cobigo, V., \& Stuart, H. (2013). Conceptualizing belonging. Disability and Rehabilitation, 35(11-13), 1026-1032.

Maslow, L. A. (1954). Motivation and personality. New York, NY: Harper.

May, V. (2015). Self, belonging and social change. Sociology, 45, 363-378.

Mellor, D., Stokes, M., Firth, L., Hayashi, Y., \& Cummins, R. (2008). Need for belonging, relationship satisfaction, loneliness, and life satisfaction. Personality and Individual Differences, 45, 213-218.

Mead, G. H. (1934/1983). Mind, self and society, from the standpoint of social behaviourist. Chicago, IL: University of Chicago Press.

Morgan, D. H. (1996). Family connections. An introduction to family studies. Cambridge; MA: Polity Press.

Morgan, D. H. J. (1999). Risk and family practices: Accounting for change and fluidity in family life. In E. B. Silva \& C. Smart (Eds.), The new family? (pp. 13-30). London: Sage.

Morgan, D. H. J. (2011). Rethinking family practices. Basingstoke: Palgrave Macmillan.

Nielsen, L. (1999). Stepmothers: Why so much stress? A review of the research. Journal of Divorce \& Remarriage, 30, 115-148. doi: 10.1300/J087v30n01_08

Nielsen, L. (2014). Shared physical custody: Summary of 40 studies on outcomes for children. Journal of Divorce \& Remarriage, 55(8). 613-635. doi: $10.1080 / 10502556.2014 .965578$

Oswald, R, F. (2002). Inclusion and belonging in the family rituals of gay and lesbian people. Journal of Family Psychology, 16(4), 428-436.

Parsons, T. (1956). The American family: Its relations to personality and to the social structure. In: T. Parsons, \& R. F. Bales (Eds.), Family, socialization and interaction process (pp. 3-33). London: Routledge \& Kegan Paul. 
Perälä-Littunen, S. (2007). Gender equality or primacy of the mother? Ambivalent descriptions of good parents. Journal of Marriage and Family, 69, 341-351. doi: 10.1111/j.1741-3737.2007.00369.x

Polkinghorne, D. E. (1988). Narrative knowing and the human Sciences. State University of New York Press.

Ribbens McCarthy, J., Edwards, R., \& Gillies, V. (2003). Making families. Moral tales of parenting and step-parenting, York: Sociology press

Riessman, C. (1993). Narrative analysis. qualitative research methods (Vol. 30). Newbury Park, CA: Sage Publications. New York Press.

Salonen, E., Laakso, M.-L., \& Sevón, E. (2016). Young children in day and night-care: negotiating and constructing belonging during daily arrivals. Early Child Development and Care, doi: 10.1080/03004430.2016.1146717

Salwen, L. V. 1990. The myth of the wicked stepmother. Women and Therapy, 10, 117-125.

Shapiro, D. N., \& Stewart, A. J. (2011). Parenting stress, perceived child regard, and depressive symptoms among stepmothers and biological mothers. Family Relations, 60, 533-544. doi: 10.1111/j.1741-729.2011.00665.x

Smart, C. (2007). Personal life. New directions in sociological thinking. Cambridge, MA: Polity Press.

Somers, M. R. (1994). The narrative constitution of identity: A relational and network approach. Theory and Society, 23(5), 605-649.

Southerton, D. (2012). Habits, routines and temporalities of consumption: From individual behaviours to the reproduction of everyday practices. Time \& Society $22,335-355$.

Stewart, S. D. (2005). Boundary ambiguity in stepfamilies, Journal of Family Issues, 26, 1002-1029, doi: 10.1177/0192513X04273591. 
Strayhorn, T. L. (2008). A hierarchical analysis predicting sense of belonging among Latino college students. Journal of Hispanic Higher Education, 2, 301-320.

Strazdins, L., \& Broom, D. H., (2004). Acts of love (and work): Gender imbalance in emotional work and women's psychological distress. Journal of Family Issues, 25, $356-378$

Thompson, J.B. (1996). Tradition and self in a mediated world. In P. Heelas, S. Lash \& P. Morris (Eds.), Detraditionalization. Cambridge, MA: Blackwell, 89-108.

Vandemark, L. M. (2007). Promoting a sense of self, place, and belonging in displaced persons: The example of homelessness. Archives of Psychiatric Nursing, 21, 241-248.

Watson, P. A. (1995). Ancient Stepmothers. Myth, misogyny \& reality. Leiden: Brill.

Weaver, S., \& Coleman, M. (2005). A mothering but not a mother role: A grounded theory study of the non-residential stepmother role. Journal of Social and Personal Relationships, 22, 477-497.

Weeks, J. (1990). Coming out: Homosexual Politics in Britain from the Nineteenth century to the present, London: Quartet Books. 